\title{
Лапароскопічна корекція рецидивних пахвинних гриж у дітей
}

\author{
V. M. BAIBAKOV
}

Dnipropetrovsk Medical Institute of Traditional and Non-traditional medicine

\section{LAPAROSCOPIC CORRECTION OF RELAPSE INGUINAL HERNIA IN CHILDREN}

Повторна операція з приводу рецидиву пахвинної грижі у дітей, яка виконується традиційним доступом у пахвинній ділянці, завжди ускладнюється наявністю грубих рубців та порушенням звичайних анатомічних відношень між органами та тканинами пахвинної ділянки. Висока травматичність повторного втручання також ускладнюється наявністю зрощень між кремастерним м'язом та елементами сім'яного канатика у хлопчиків та значними спайками в ділянці круглої зв’язки матки у дівчат, що призводить до грубого порушення усіх ланок дренажних систем яєчка у хлопчиків та розвитку порушень васкуляризації яєчника у дівчат.

Наведені чинники спонукають дитячих хірургів до пошуку нових, менш травматичних та високоефективних методів операційного лікування рецидивних пахвинних гриж у дітей.

Цим завданням повною мірою відповідає вдосконалений нами спосіб лапароскопічної корекції рецидивної пахвинної грижі з проведенням інтраопераційного УЗД-контролю пахвинної ділянки з боку втручання. За період з 2013 до 2015 р. у хірургічному відділенні КЗ “ДСКМЦМД ім. проф. М. Ф. Руднєва” ДОР м. Дніпра було виконано 18 лапароскопічних втручань при рецидивних пахвинних грижах у дітей, яким перше втручання виконували традиційним доступом у пахвинній ділянці. Всі діти були у віці до 3 років. При аналізі випадків рецидиву пахвинних гриж дійшли висновку, що рецидиви з'являлися у дітей раннього віку i, частіше, після операційних втручань 3 приводу защемлених пахвинних гриж, які оперували традиційними способами.

Таким чином, запропонований нами спосіб лапароскопічної корекції рецидивних пахвинних гриж дозволяє ліквідувати грижовий мішок без додаткового травмування структур пахвинного каналу, які перебувають у стані рубцевого процесу, що виник після попереднього хірургічного втручання в пахвинній ділянці. Крім того, гарний косметичний ефект операції перешкоджає формуванню повторних спайок та грубих післяопераційних рубців.

У ході проведеної нами роботи доведено, що серед заходів, які спрямовані на відновлення порушень дренажних систем яєчка при порушенні облітерації піхвового відростка очеревини у хлопчиків та для збереження васкуляризації яєчника у дівчат, головне місце займають: своєчасне повторне хірургічне лікування дітей, використання патогенетично обгрунтованих способів хірургічної корекції патології на рівні глибокого пахвинного кільця з використанням сучасної лапароскопічної техніки.

Repeated surgery for inguinal hernia recurrence in children performed by traditional access to the inguinal area, always has complications such as presence of rough scars and disruption to the normal anatomical relationships between organs and tissues of inguinal area. High traumatic re-intervention, also has complications such as presence of adhesions between elements of cremasteric muscle and spermatic cord in boys and significant spikes in the area round ligament of the uterus in girls, leading to a gross disorder of all levels of drainage testes in boys and development of vascularization ovarian disorders in girls.

These factors encourage pediatric surgeons to find new, less traumatic and highly efficient methods of surgical treatment of recurrent inguinal hernias in children.

These objectives are fully satisfied by our improved method of laparoscopic correction of recurrent inguinal hernias with conducting intraoperative ultrasound control of inguinal area in the intervention part. During the period from 2013 to 2015 in the Surgical Department of "Specialized Clinical Medical Centre of a Mother and a Child by Prof. M. Ph. Rudniev" in Dnipro, Ukraine there were performed 18 laparoscopic interventions for recurrent inguinal hernias in children whose first intervention was performed by traditional access to the inguinal area. All the children were under the age of 3 years. While analyzing the cases of relapse of inguinal hernias we found that relapses appear in young children, and more often after surgery on strangulated inguinal hernias, which are operated by traditional methods.

Thus, our proposed method of laparoscopic correction of recurrent inguinal hernias allows eliminating the inguinal hernia without further injury of inguinal canal structures that are in a state of rumen process that came after previous surgery in the inguinal area. In addition, good cosmetic effect of repeated surgery prevents the formation of adhesions and postoperative coarse scars.

In the course of our work, it is proved that among the measures aimed at the restoration of the drainage of the testes in disorder of the obliteration of the vaginal process of peritoneum in boys and to preserve the vascularization of the ovary in girls is dominated: timely re-surgical treatment of children, the use of pathogenesis reasonable way of surgical correction pathology at deep inguinal ring using modern laparoscopic technique. 
Постановка проблеми і аналіз останніх досліджень та публікацій. Рецидиви пахвинних гриж у дітей частіше виникають у ранньому віці, що пов'язано зі складними анатомо-функціональними особливостями структур пахвинної ділянки та незрілістю сполучної тканини [2]. Ці фактори зумовлюють технічну складність виконання операційного втручання та потребують від хірурга досконалого знання анатомії пахвинної ділянки у дітей раннього віку та високого рівня практичної підготовки [1, 3, 4].

При аналізі вітчизняної та іноземної літератури $з$ даної теми звертає на себе увагу відсутність єдиних патогенетично обгрунтованих поглядів не тільки на окремі часткові питання, але й на такі кардинальні проблеми, як:

- визначення оптимальних термінів повторної операції;

- вибір оптимальних методів повторної хірургічної корекції;

- оптимізація принципів післяопераційного ведення хворих [2, 9, 14].

При аналізі літератури та на підставі власного досвіду дійшли висновку, що результати лікування рецидивних пахвинних гриж у дітей не повною мірою задовольняють науковців та клініцистів великим відсотком післяопераційних ускладнень, насамперед, з боку репродуктивних органів [5, 7, 8]. Висока травматичність повторної операції в пахвинній ділянці з рубцюванням та порушенням нормальних анатомічних відношень між структурами пахвинної ділянки може привести до негативних наслідків з боку репродуктивних органів як у хлопчиків, так і в дівчат у фертильному періоді. Тому використання лапароскопічної корекції рецидивної пахвинної грижі після проведеного традиційного втручання в пахвинній ділянці значно зменшує ризик додаткової травматизації структур пахвинної ділянки у дітей. Вирішення цієї проблеми $\epsilon$ важливим кроком у боротьбі за репродуктивне здоров'я нації та збереження повноцінної сім'ї $[6,10,12]$.

Мета роботи: підвищити ефективність хірургічного лікування дітей із рецидивами пахвинних гриж шляхом удосконалення операційної тактики.

Матеріали і методи. Спосіб лапароскопічної корекції рецидивних пахвинних гриж у дітей. За період з 2013 до 2015 р. у хірургічному відділенні КЗ “ДСКМЦМД ім. проф. М. Ф. Руднєва” ДОР м. Дніпра було виконано 18 лапароскопічних втручань із приводу рецидивних пахвинних гриж у дітей, яким перше втручання виконували традиційним доступом у пахвинній ділянці. Всі діти бу- ли у віці до 3 років (хлопчиків - 12, дівчат - 6). При аналізі випадків рецидиву пахвинних гриж дійшли висновку, що рецидиви з'являлися у дітей раннього віку i, частіше, після операційних втручань з приводу защемлених пахвинних гриж, які оперували традиційними способами.

Рецидиви пахвинних гриж пропонуємо оперувати лапароскопічним способом з інтраопераційним УЗД-контролем. Основними причинами рецидивів пахвинних гриж у дітей вважаємо порушення техніки втручання під час першої операції. Це може бути:

- видалення лише дистальної частини грижового мішка;

- видалення не грижового мішка, а навколишніх тканин;

- порушення прийомів ушивання апоневроза зовнішнього косого м'яза живота;

- виконання операційного втручання не дитячими хірургами, а хірургами загальної практики без достатнього досвіду.

Наведені чинники спонукають дитячих хірургів до пошуку нових, менш травматичних та високоефективних методів операційного лікування рецидивних пахвинних гриж у дітей. Цим завданням повною мірою відповідає запропонований нами спосіб лапароскопічної корекції рецидивної пахвинної грижі з проведенням інтраопераційного УЗД-контролю пахвинної ділянки з боку втручання.

Результати досліджень та їх обговорення. Спосіб виконується таким чином. Під ендотрахеальним наркозом трансумбілікально встановлюють порт D-5 мм, через який у черевну порожнину вводять лапароскоп D-5 мм. Тиск $\mathrm{CO}_{2}$ у черевній порожнині підтримується на рівні 8-10 мм рт. ст. Оглядаються внутрішні пахвинні кільця, встановлюється наявність рецидивної пахвинної грижі.

Під час накладання карбоксиперитонеуму інтраопераційно виконують УЗД-контроль пахвинної ділянки з боку операції. Оцінюють наявність газу в грижовому мішку, його форму, розміри та розташування, стан апоневроза. У випадку, коли грижовий мішок заповнено газом на протязі, а стан апоневроза відповідає проведеній пластиці, виконують лише ушивання внутрішнього пахвинного кільця після гідравлічного препарування та введення тканинного клею в просвіт грижового мішка. Виконують гідропрепарування тканин навколо внутрішнього пахвинного кільця 0,9 \% розчином хлориду натрію. Після цього накладають кисетний шов у ділянці внутрішнього пахвинного кільця. Для цього використовують пролен 2-0. У шов беруть очеревину в місці, де проведено гі- 
дравлічне препарування тканин. Під відеоконтролем, у точці проекції внутрішнього пахвинного кільця, яка визначається шляхом натискання на передню черевну стінку, у пахвинний канал вводять тупокінцеву голку G-19 з ниткою пролен 2-0, що не розсмоктується, яку за допомогою гідропрепарування 0,9 \% розчином хлориду натрію проводять таким чином, щоб нитка проходила під очеревиною по одній зі стінок пахвинного каналу. При введенні нитки формують петлю. Потім голку виймають, а петлю залишають у черевній порожнині. У голку вставляють інший кінець нитки й через той же прокол нитку проводять під очеревину по протилежній стінці пахвинного каналу так, щоб ії̈ кінець проходив через вже сформовану петлю.

Потім голку виймають, обидва кінці нитки виводять на передню черевну стінку. Перед затягуванням сформованого навколо внутрішнього пахвинного кільця шва в просвіт пахвинного каналу вводять однокомпонентний тканинний клей із діючою речовиною n-бутилціаноакрилат, після чого вузол затягують.

Кінці нитки зрізують, оцінюють контроль герметичності кисетного шва. При діагностуванні некротичних змін чи підозрі на них рекомендуємо продовжувати операцію відкритим доступом.

Якщо, за даними УЗД, має місце розходження апоневроза $з$ формуванням дефекту, виконують міні-розріз шкіри до 2,0 см довжиною та ушивання дефекту апоневроза. Ушивання внутрішнього пахвинного кільця робиться після гідравлічного препарування та введення тканинного клею в просвіт грижового мішка з боку черевної порожнини.

Гідропрепарування тканин у ділянці внутрішнього пахвинного кільця з боку черевної порожнини $0,9 \%$ розчином $\mathrm{NaCl}$ залучається як додатковий метод профілактики кровотечі внаслідок травмування судин. Гідропрепарування тканин внутрішнього пахвинного кільця з використанням 0,9 \% розчину $\mathrm{NaCl}$ істотно знижує ризик травмування судин.

$\mathrm{N}$-бутилціаноакрилат (енбукрилат) $є$ медичним клеєм рідкої форми, що полегшує нанесення його через просвіт грижового мішка, біосумісним, гемостатичним, антибактеріальним, негістотоксичним препаратом, що запобігає утворенню вторинних запальних реакцій, а синій колір добре індукує в полі зору операційного простору. Його введення у просвіт грижового мішка посилює надійність кисетного шва, виключає ризики рецидиву грижі, зменшує час хірургічного лікування. Властивості клею $є$ достатніми для перевершення ефективності, зменшення травматичності та забезпечення доброго косметичного ефекту.
Середній термін перебування в стаціонарі склав 2 доби. Висока ефективність способу підтверджена клінічно та за допомогою УЗД-контролю.

Результати дослідження дають змогу на практиці звести до мінімуму як розвиток ускладнень, так і ризик розвитку післяопераційних ускладнень.

Приклад. Хворий К. Олексій віком 2 роки госпіталізований в хірургічне відділення К3 “ДСКМЦМД ім. проф. М. Ф. Руднєва” ДОР м. Дніпра 22.11.2015 р. зі скаргами батьків на грижове випинання в пахвинній ділянці праворуч. Із анамнезу відомо, що за два місяці до того хлопчик був оперований у тому ж відділенні з приводу защемлення пахвинної грижі праворуч. Дитину було госпіталізовано через 12 год після защемлення. Після передопераційної підготовки, під загальним знеболюванням, було проведено грижорозтин за Дюамель I праворуч. Післяопераційний період перебігав без особливостей. Хлопчик був виписаний із відділення на 3 добу після операції. Через 1 місяць після операції батьки звернули увагу на появу випинання в пахвинній ділянці праворуч. Повторно звернулись на консультацію до дитячого хірурга.

Хлопчик був направлений у хірургічне відділення для проведення операційного втручання. При огляді правої пахвинної ділянки пацієнта звертає на себе увагу грижове випинання 2,0×3,0 см, яке вільно вправляється в черевну порожнину. В пахвинній ділянці праворуч післяопераційний рубець до 3,0 см довжиною без ознак запалення. Було виконано УЗД із доплерографією тестикулярних судин обох яєчок. Тестикулярна артерія праворуч: RI=0,95; Vmax=3,47 cм/с. Тестикулярна артерія ліворуч: $\mathrm{RI}=0,97 ; \mathrm{Vmax}=3,8 \mathrm{~cm} / \mathrm{c}$. Діагноз: рецидивна пахвинна грижа праворуч. Рекомендоване операційне втручання - лапароскопічна корекція запропонованим способом.

Під час накладання карбоксиперитонеуму інтраопераційно виконали УЗД-контроль пахвинної ділянки з боку операції. Газ у грижовому мішку спостерігали на всьому його протязі, розходження апоневроза зовнішнього косого м'яза живота не спостерігали. Прийнято рішення щодо накладання кисетного шва на внутрішнє пахвинне кільце. Проведено гідропрепарування тканин навколо внутрішнього пахвинного кільця 0,9 \% розчином хлориду натрію. Після цього було накладено кисетний шов у ділянці внутрішнього пахвинного кільця. 3 цією метою використовували пролен 2-0 та тупокінцеву голку G-19. Перед затягуванням сформованого навколо внутрішнього пахвинного кільця шва в просвіт пахвинного каналу введено однокомпонентний тканинний клей із діючою речовиною n-бутилціаноакрилат. 


\section{З ДОСВІДУ РОБОТИ}

Хлопчик був виписаний із хірургічного відділення на другу добу після операції. Через місяць здійснили УЗД із доплерографією тестикулярних судин яєчок. Яєчка були розташовані в калитці, тестикулярна артерія праворуч: $\mathrm{RI}=0,96$; $\operatorname{Vmax}=3,7$ cм/c, за показниками кровообігу наближалась до норми. Спостерігали поліпшення показників кровообігу порівняно зі станом до операції: зниження індексу резистентності $(0,607-0,600)$, підвищення пікової систолічної швидкості кровообігу та кінцевої діастолічної швидкості кровообігу. Порушень кровообігу, атрофії яєчка та грижового випинання не спостерігали.

Таким чином, запропонований нами спосіб лапароскопічної корекції рецидивних пахвинних гриж у дітей дозволяє ліквідувати грижовий мішок без додаткового травмування структур пахвинного каналу, які перебувають у стані рубцевого процесу, що виник після попереднього хірургічного втручання в пахвинній ділянці. Крім того, гарний косметичний ефект операції перешкоджає формуванню повторних спайок та грубих післяопераційних рубців.

Ефективність запропонованого способу доведена клінічними даними та результатами УЗД у різні терміни після операції. Малотравматичність

\section{СПИСОК ЛІТЕРАТУРИ}

1. Акбашев Р. Н. Лапароскопическое лечение ущемлённых паховых грыж у детей : автореф. дис. на соискание ученой степени канд. мед. наук : спец. 14.00.35 “Детская хирургия” / Р. Н. Акбашев. - Уфа, 2006. -23 с.

2. Ахтемійчук Ю. Т. Топографо-анатомічне обгрунтування хірургічних операцій / Ю. Т. Ахтемійчук, П. М. Скорейко // Український морфологічний альманах. - 2005. - Т. 3, № 3. C. 3-8.

3. Горбатюк О. М. Діагностика судинних розладів яєчка у дітей при його хірургічній патології / О. М. Горбатюк : матеріали конф., присвяченої 30-річчю клініки судинної хірургії у Львові “Актуальні питання ангіології”, м. Львів, 5-7 жовтня 2000 р.). - Львів, 2000. - С. 74.

4. Горбатюк О. М. Загальні закономірності патогенезу чоловічої неплідності, обумовленої патологією вагінального відростка очеревини / О. М. Горбатюк // Урологія. - 2000. - № 2. - C. 47-49.

5. Грицуляк Б. В. Стан макро- та мікроциркуляторного русла і паренхіми яєчка в умовах прямої пахвинної грижі у чоловіків репродуктивного віку / Б. В. Грицуляк, В. Б. Грицуляк, О. Є. Халло // Галицький лікарський вісник. - 2010. № 1. - C. 26-27.

6. Грицуляк Б. В. Структурно-функціональні особливості кровоносного русла і паренхіми яєчка та над'яєчка у чоловіків віком 75-90 років / Б. В. Грицуляк, В. Б. Грицуляк, О. І. Готюр // Науковий вісник Ужгородського національного університету. - 2013. - Вип. 1 (46). - С. 12-15. - Серія “Медицина”. 7. Дронов А. Ф. Эндоскопическая хирургия у детей / та патогенетична обгрунтованість запропонованого способу лапароскопічної корекції рецидивних пахвинних гриж у дітей дозволяє нам рекомендувати ці методи для широкого застосування в дитячій хірургії.

Висновки. 1. При рецидиві пахвинної грижі розлади тестикулярного кровообігу у хлопчиків та порушення васкуляризації яєчника у дівчат $є$ факторами ризику розвитку безпліддя в репродуктивному періоді.

2. Серед заходів, які спрямовані на відновлення порушень дренажних систем яєчка при вадах облітерації піхвового відростка очеревини у хлопчиків та збереження васкуляризації яєчника у дівчат, при повторному втручанні головне місце займає використання патогенетично обгрунтованого способу хірургічної корекції патології на рівні глибокого пахвинного кільця з використанням сучасної лапароскопічної техніки.

3. Ультразвуковий метод дослідження з використанням доплерівських технологій $є$ високоефективним способом оцінки як анатомічних показників, що стосуються розмірів яєчка у хлопчиків та яєчника у дівчат, судин, стану паренхіми репродуктивних органів, так і функціональних показників.

А. Ф. Дронов, И. В. Поддубный, В. И. Котлобовский. - М. : ГЭОТАР-Мед., 2002. - 437 с.

8. Патогенез снижения фертильности при аутоиммунных реакциях против сперматозоидов / В. А. Божедомов, М. А. Николаева, И. В. Ушакова [и др.] // Акушерство и гинекология. - 2012. - Т. 8, № 2. - С. 64-69.

9. Стальмахович В. Н. Эндоскопическое или открытое паховое грыжесечение / В. Н. Стальмахович : материалы Российского симпозиума детских хирургов “Хирургия патологии полового развития у детей” (г. Саратов, 24-26 апреля, 2007 г.). - Саратов, 2007. - С. 48.

10. Яцків О. Г. Причини і форми чоловічого непліддя та методи діагностики еякуляту як основного показника чоловічого здоров’я / О. Г. Яцків, А. Т. Тарновська // Вісник Львівського університету. - 2012. - Вип. 60. - С. 4-20. - (Серія "Біологічна").

11. Carneiro P. M. Occurrence of contralateral inguinal hernia in children following unilateral inguinal herniotomyt / P. M. Carneiro, L. Rwanyuma // East. Afr. Med. J. - 2004. - Vol. 81, № 11. - P. 574-576.

12. Owings E. P. A new technique for laparoscopic exploration to find contralateral patent processus vaginalis / E. P. Owings, K. E. Georgeson // Surg. Endosc. - 2000. - Vol. 14, № 2. - P. 114-116.

13. Schier F. Direct inguinal hernias in children: laparoscopic aspects / F. Schier // Pediatr. Surg. Int. - 2010. - Vol. 16, № 8. P. 562-564.

14. Tan H. L. Laparoscopic repair of inguinal hernias in children / H. L. Tan // J. Pediatr. Surg. - 2001. - Vol. 36, № 5. - P. 880-833. 